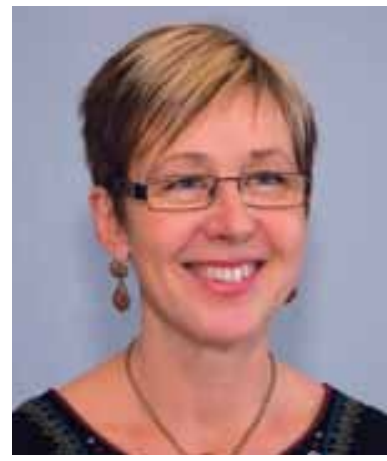

KARIN HAVEMOSE

PhD, Head of Research \&

Education, Vandalorum,

Värnamo, Sweden

\title{
The Encyclopedia Hands
}

\section{FROM DESIGN THINKING TO DESIGN MAKING}

BY KARIN HAVEMOSE

Keywords:

Creativity in practice, Designmaking,

Tacit knowledge, Theory of knowledge,

Designphilosophy 
This article deals with creativity in practice and reveals the complex web of knowledge and skills that are in the things we create. Immaterial values such as traditions, memories and intentions are made visible. Also dimensions from the philosophy of knowledge are revealed: reflective judgement, aesthetic sensitivity and accountability for doing good work. The epistemology of the article is based on the theory of hermeneutic experience and empirical examples are gathered from the author's book Things in motion - the design process (2012).

\section{INTRODUCTION}

When artistic objects separate both from conditions of origin and from human conditions, a wall is built around them. To really understand the meaning of artistic objects, we have to forget them for a while and make a detour. We must begin to understand in the raw (Dewey, 1934, chap. 1). This article makes a pragmatic detour from the existing paradigm in the design research community - design thinking - into the concrete world of design making (Cross, 2001; Dorst, 2011). The epistemology is based on examples from professional design practitioners' personal reflections on their work process and on artistic objects (Nordenstam, 2010). The reflections are mirrored in texts from both the philosophy of design and the philosophy of knowledge where analogies and different perspectives are made visible and explored (Havemose, 2012). The aim is to treat creativity in practice and highlight the complex web of skills and knowledge that is embedded in the things we create and in their creation itself (Buchanan, 2001).

\section{THE ENCYCLOPEDIA POSTERS}

Denis Diderot was one of the members of the inner circle of the French Enlightenment philosophers who between 1751 and 1777 compiled and published Encyclopaedia or a Systematic Dictionary of the Sciences, Arts and Crafts. Besides being a comprehensive Encyclopedia it was a gigantic enlightenment and education project that compiled skills, knowledge and things that humans had developed in different areas. One question that occupied Diderot's mind was what is it that people learn by learning about their limits? One way to answer the question was to find out how people worked. The method he used was to ask them, like a modern anthropologist. He wrote:

We addressed ourselves to the most skilled workers in Paris and the kingdom at large. We took the trouble to visit their workshops, to interrogate them, to write under dictation from them, to follow out their ideas, to define, to identify the terms peculiar to their profession (Sennett, 2008, p. 98).

The project ran into trouble because much of the knowledge the craftsman possessed could not be put into words. Diderot remarked that among a thousand craftsmen you will be lucky to find a dozen who are capable of explaining the machines, the tools and the things they produce with any clarity. This is not because they are stupid, argued Diderot, it is merely because it is beyond human capacity to put human practice into words. This is perhaps one of the fundamental human limits, a phenomenon usually referred to as tacit knowledge. One way around that limit was the use of images instead of words, and the results are the beautiful Encyclopedia posters.

I got in touch with the posters through the modern French Philosopher Roland Barthes's essay Image, raison, déraison (Barthes, 1964). The posters move the viewer into the world of matter, things, humans and making. They illustrate the knowledge man has developed in various fields: natural sciences, technology and the arts. Looking at them you realize that there are huge numbers of different things that man has designed, things with different shapes made with different matter and materials. Some of them are gigantic: parks, ships and buildings. Others are smaller: corks, playing cards and artificial flowers. Some of the posters are divided into parts that illustrate the work process from different perspectives. In the lower part different tools, materials and instruments are shown. There are ladles and bowls, a rolling pin that rests on dough and a basket on a shelf with something in it. On some of the posters human hands appear, demonstrating the different tools, materials, etc. The hands are separated from the rest of the body; they float freely in the air holding a tool or a piece of matter. On the upper part of the poster, which Barthes calls the "vignette", the hand is part of a human body. There are humans working together in a workshop deeply involved in a work process. It is an intensive and complex process, with various components where the material is chopped into smaller pieces, divided, dissolved and transformed into something new, a 'new thing'. From the workshop's window there are glimpses of the surroundings, there are houses and a boat is nearing the workshop from a canal. 


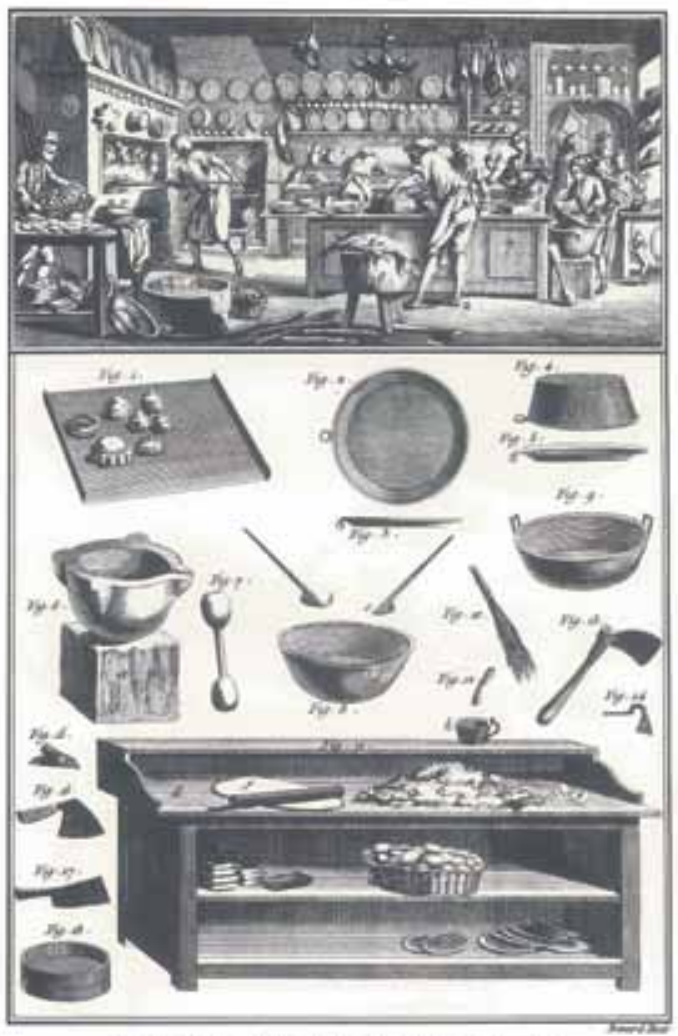

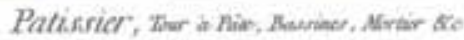

Picture 1: Patissier (Poster 5)

\section{THE SIGN OF THE MAKER}

The encyclopaedia posters place the man as a central character in a world of matter and material. The man reaches out into the environment and with his hands and tools transforms, creates and re-creates. In Barthes reflection on the posters the thing appears as man's 'signature' in the world. He wrote:

The Encyclopedia man inserts human signs into all of nature. In the Encyclopedia landscape you are never alone. In the midst of the natural elements there is always a product with which man feels allied. The thing is man's signature in the world." (author's translation from Swedish, p. 24)

The word signature leads thought to the word 'sign'. The media philosopher Vilém Flusser explored the root and meaning of the word design (Flusser, 1999). It derives from the Latin signum, meaning sign. As a noun it means

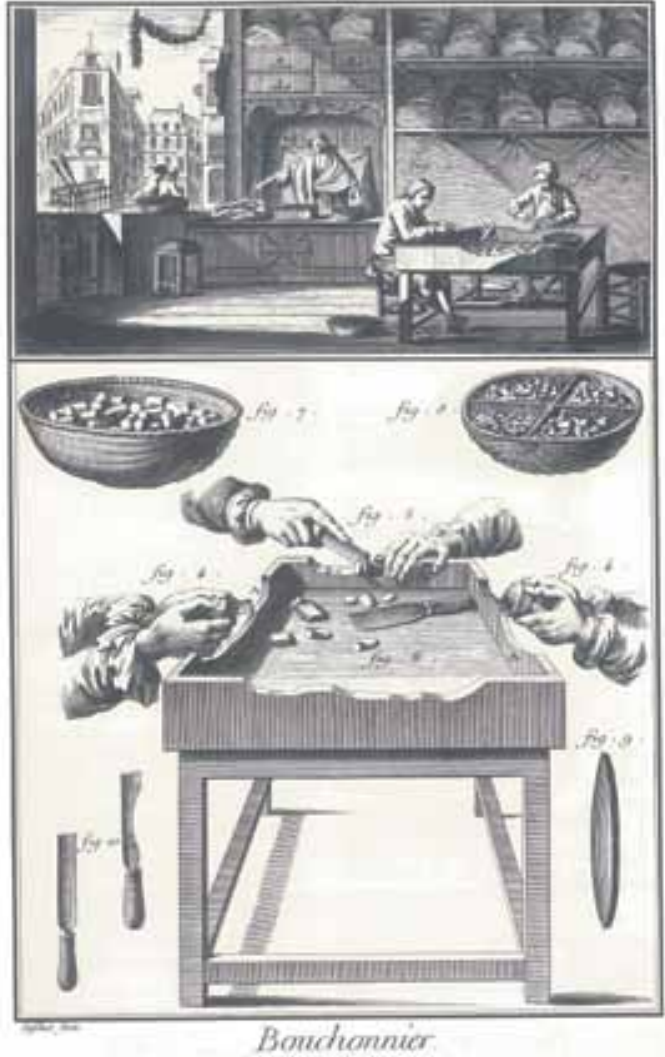

Picture 2: Bouchonnier (Poster 8)

among other things, 'intention', 'plan' and 'aim'. As a verb (to design) the meaning includes 'to concoct something, 'to simulate', 'to draft', 'to sketch', 'to fashion' (p.17). Flusser also added some of the associated contexts and significant words in which the word design occurs, for instance mechanics and machine. In the light of the Greek mechos, which is associated with 'a device designed to deceive' (e.g. the Trojan Horse), the designer appears as 'a cunning plotter laying out his traps'. In the book The Craftsman (2008, chap. 4) the sociologist Richard Sennett related 'sign' more closely to the maker. It could be the maker's mark on a crafted item made of metal, wood or clay. It could also be a much simpler sign, for instance a symbol on a brick made by a Roman slave. Sennett asked what kind of signal the sign actually is. It can be a signal of who did this and maybe add some economic and/or political value to the item. It could also be a signal of the maker's presence. By putting a signature on the brick the Roman slave said, "I exist!" In that sense the maker's 'sign' is a mark of presence (p.130). 
During a visit to the Swedish furniture company Källemo, Karin Lundh guided me through the exhibition hall and told the story behind the different pieces of furniture. She said that they all have their own marks or imprints of the maker. She used the word self-portrait in the sense that the furniture is 'loaded' with the presence of the maker. The cabinet designed by Sigurdur Gustafsson carries his memories from a boat graveyard situated on the northern coast of Iceland. "You also recognize the typical corrugated sheet that the Icelandic houses are made of", said Karin. Other marks are the makers' typical idioms, their personal expressions and intentions. It could be a detail in a chair's transition between different dimensions, the position of the buttons on the couch or echoes from a whole country's cultural expression and attribute.

In the theory of the hermeneutic experience our memory, history and tradition are all essential parts of our selfunderstanding. They form and constitute the horizon from which we orient ourselves, take position, interpret and understand the world. In Truth and method (1960) HansGeorg Gadamer discussed memory and filled it with a more significant and essential meaning. He argued, “... it is time to rescue the phenomenon of memory from being regarded merely as a physiological faculty and to see it as an essential element of the finite historical being of man" (p.14). It is not a memory of anything and everything. One has a memory for some things, and not for others; one wants to preserve one thing in memory and banish another. The memory is a 'something' that is formed in you (p.21).

\section{TUT'S CHAIR}

In the essay Tut's chair (1988) the Swedish art carpenter Thomas Tempte reflects on a meeting with Pharaoh Tutankhamen's chair. It is a little white frayed chair that an Egyptian furniture maker made around 1350 BC. It is placed behind a glass wall at an exhibition, and when Tempte looked at it, it fascinated him. It could have been made in our time, but it was made with completely different intentions than those Tempte was familiar with. He put up a photo of the chair on the bulletin board above his work desk. Sometimes he has to take it down because it attracts too much of his attention. He began to explore the tools that were used at the time of the chair's construction: screwdrivers, chisels and saws. When doing that several questions arose. How long did it take to make the chair? Did they use templates, and if so, were they used over and over again? Did they use a few standard sizes, or other modules? (p.70). Tempte's respect for the furniture maker who once made the chair grew stronger. He was not satisfied with simply trying to understand the implications of the making - he decided to make the chair. In the process of reconstruction its secrets began to reveal themselves and its history emerged. Tempte discovered that it involves many complex and technical solutions. It must have been made by the 'fitting method' in which you put the pieces together, measure, take them apart, adjust them and then reassemble them again. There are symbols, hieroglyphs and cultic messages where lilies and papyrus flowers have their own meanings and significance. The chair is 'a lion' standing on its four paws, not touching the ground. It rather 'stands above the ground' on small heels with cantilevers that prevent it from sinking into a soft surface. A falcon appears in the middle of the backrest. It is the Falcon God that Pharaoh had a covenant with. Tempte had to put his modern machines aside and travel back to the same technological stage as his Egyptian representatives. He found that his predecessor had a completely different perception of forces and counter-forces. Their sense of proportion must have been incredibly trained. In the reconstruction Tempte met his predecessor's professional knowledge and skill and care is the message that is reflected in all parts of the chair. He wrote:

Has the chair any expression that can be traced to the man who with his hands and active mind once created it? I would say so. To be able to materialize an object that surely many people have been involved in and have given directions about requires a very special ability, a creative intellect. This combined with a deeply personal and refined approach (author's translation from Swedish, p.70).

Picture 3: Tomas Tempte's reconstruction of Tut's chair (Photo: Torndahl)

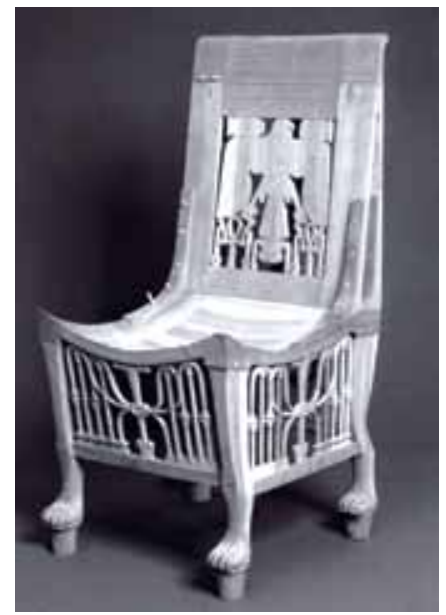


When Tempte reconstructed the chair he had a silent conversation with his predecessor, in a common language. According to the pragmatic philosopher Ludwig Wittgenstein it is "to imagine a form of life" (Johannessen, 2006, p. 288). It is the ability to use our senses and reflect on what we perceive, we use our imagination to give 'a something' a meaning. In this case Tempte used the mastery of the carpenter's practice, and in his 'silent conversation' with the Egyptian carpenter they share a form of life. In the light of the hermeneutic theory the medium that communicates the work is in principle total - the work presents itself through it and in it (Gadamer, 1960, p. 118). Memories and past history meet present time in a moment of 'contemporaneousness'. It is the moment when horizons meet. Thus horizons are not stable or closed, rather they are open and in constant motion. We move with them and they move with us. Hence aesthetics becomes the history of worldviews, a history of 'truth' manifested in the mirror of art (p. 119).

\section{STANDING ON THE SHOULDERS OF GIANTS}

The phrase "standing on the shoulders of giants" is a metaphor used to illustrate the idea that knowledge is a cumulative process developed from human to human. Previous distinguished scientists' and artists' work sets the standard and forms the framework that future scientists and artists operate in. In august 2009 I interviewed the Swedish furniture designer Dan Ihreborn. Dan told me that a great source in developing new things is technologies, manufacturing technologies, because then you can see what can be done with it, what can be solved with it. You collect all the impressions and ideas you have and try to make something out of them. Some years ago he started to work on his own collection, making full-scale experiments with ideas that he had, although there were no clients who requested them. It is extremely valuable to test the most advanced ideas in full scale, continued Dan. It is personal development. In his study stands a bureau that he designed seven years ago. In this case it was the craftsman Georg Haupt (1741-84) and the intarsia technique that gave him the idea. Dan told me that when he sees something that is unfairly treated or neglected he wants to grab it and put it into a new age. "It's a bit titillating and exciting to work with an old technique. Intarsia is made of small pieces of different veneers, and there are actually hundreds of different types and varieties to choose from. You draw a pattern and then you cut out pieces, detail by detail, that are assembled into a whole. Intarsia was common in the 50's, also in bureaus.
Over time intarsia became obsolete and also too expensive to produce." Dan continued, "It's a typical example of how new forms can be created. In this case I wanted to use a technique that for several of reasons hadn't been used for a long time. I put the technology in a new context and tried to make something new out of it. It resulted in a bureau that I have called Pink Jaguar.”

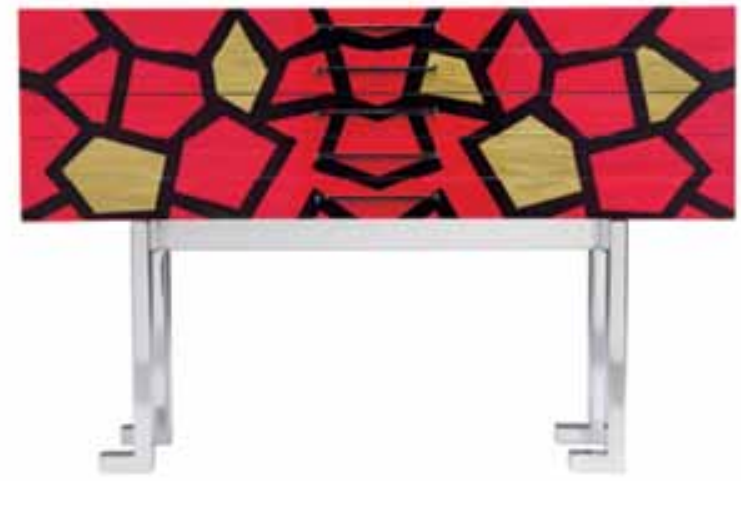

Picture 4: Pink Jaguar (Dan Ihreborn)

Dan grew up in a district with a long tradition of designing and manufacturing furniture. That is a craft that includes different techniques, different styles and models where Georg Haupt and intarsia is one example. But are traditions not something that we should release ourselves from, especially in the innovative work process? In the book Ansvarig handling (2003) Gunnar Bergendal writes about a sculpture located in a university environment named "The man who breaks out of the rock" (p. 17). When as a young student Bergendal looked at the sculpture he saw a man who tried to break out of a rock in order to release himself from traditions and prejudices. After the years went by and Bergendal grew older, he began to see something else. He saw that the man was stuck in the rock; it was actually a part of him.

In fact our traditions, prejudices and role models are the representatives and the patterns that form the basis of our knowledge and understanding of the world. They are something that we acquire, critically examine and work with. Thus we are not born into an abstract world of vacuum, rather into a room full of life. Gadamer uses the expression the practice of a performance in the meaning "by constantly following models and developing them, a tradition is formed with which every new attempt must come to terms" (p.117). That is a practice that passes from person to person. However, the transfer is not "blind imitation", it is 
rather something that is productive:

The performing arts have this special quality: the works they deal with are explicitly left open to such re-creation and thus visibly hold the identity and continuity of the work of art open toward its future (Ibid).

The bureau Pink Jaguar carries the traces of its predecessor, yet it is something new - a new thing. Traditions shift and perhaps the criterion that determines whether something is a "correct presentation" is a highly flexible and relative one (p.118).

\section{THE SKILLED CRAFTSMAN}

Another product in Dan's collection is the metal carpet Lancelot. In this product he used laser-cutting technology as a source of inspiration. Twenty-seven metal parts, folded like a puzzle to an existing pattern, compose Lancelot. Dan got help from several companies to carry out the work. He tells me that you need access to very talented craftsmen and producers. "Without their skills and willingness to cooperate it doesn't work. And in time you'll find those who can and want to help you. With them I discuss the problems in detail. I depend on their knowledge and experience in testing and working out different solutions, especially when the shape and quality feel unsure. And the steel felt genuine", continued Dan. "It is difficult to process, but fantastic to work with. You get all the dimensions and can work with different design solutions, down to the millimeter-thin stuff. That way you get the resilience that I want to have in all my products, it gives a more active impression." I asked Dan where he got the idea for the pattern. He answered that it has its origin in laser technology. "It provides new opportunities to design without high up-front costs. Previously they used individual tools for punching out the different parts. It would have required four different tools to produce the carpet, which would have been very costly. Laser technology requires no tools, which gave the inspiration."

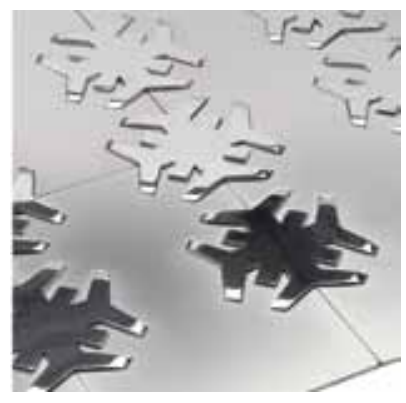

Picture 5: Detail from Lancelot (Dan Ihreborn)
The metal carpet lies on a black felt mat like a gleaming puzzle. The surface is shiny and hard. After I heard Dan's story the surface of the carpet started to dissolve and it was possible to imagine what it really contains. There are materials, thoughts, considerations, skills, technology and cooperation. It is also the effort in experimenting and developing an idea to a complete product and the confidence in the skilled men and women who have contributed to its creation. The carpet is the result of 'the joy of making' and the responsibility of making a product with care and a sense of quality. It is the work of the skilled craftsman.

Ancient Greece celebrated the skill of the craftsman through a Homeric hymn dedicated to the master god of craftsmen, Hephaestus. It goes:

Sing clear voiced Muse, of Hephaestus famed for skill. With bright eyed Athena he taught men glorious crafts throughout the world -- men who before used to dwell in caves in mountains like wild beasts (Sennett, 2008, p. 21).

In the hymn Hephaestus was honoured not only for his professional skills, but also for his cunning and ingenuity. $\mathrm{He}$ taught his craft to 'man', who took a step away from a primitive life in the caves to become a civil man in a functional and peaceful society. The word in the hymn used to characterize the craftsman was demioergos, which is a concatenation of words for audience (demios) and production (ergon). Sennett also noted that Demioergos not only included traditional crafts, but also doctors, professional singers, storytellers and lower magistrates.

\section{THE INTELLIGENT HAND}

The word craft evokes thoughts concerning the skilled hand - the intelligent hand. According to Flusser (1999) the word 'hand' derives from the word 'technology', which has its roots in the German word 'Tischler', translated into English meaning 'carpenter'. And 'carpenter' derives from the Greek byle which translated to English means wood. The basic idea is "... that wood is a shapeless material, to which the artist, the technician, gives form, thereby causing the form to appear in the first place" (p.18). Skilled and intelligent hands appear in the Encyclopedia posters. They reach out into the environment, gripping, touching, turning and transforming different matter and material to new forms. In the essay Praktikens logik (2003) Bergendal discusses the two French expressions: Comprehension intellectuelle and Comprehension par corps (pp. 61-69). Comprehension par intellectuelle is an intellectual understanding not 
bound to space and time, it is the viewer's understanding, the 'know what'. Comprehension par corps is the participant's understanding. It has a direction in time and it connects a vivid memory to a pending task for attention. Comprehension par corps is thus 'the senses and the doings understanding'. Corps also means 'human community' esprit de corps - the sense of solidarity within a community. In a professional group it is the mutual expertise, tradition and practices that create communion. In a work team representing different professions and with diverse expertises and experiences, it is the accountability for doing a good job that unites the members, an act of knowledge and responsibility.

The history of the intelligent hand takes us back more than 1.75 million years, to the time when 'man' created the first primitive tool, the hand axe. However, seventy thousand years ago something remarkable happened in our history: we created our first artistic objects in the form of ocher stones with beautifully engraved patterns (Berg, 2005). With this step the items we made became something more than functional tools, rather they became artistic objects carrying a sign and a message from the maker.

\section{CONCLUSION}

Submerged beneath the explicit and implicit levels of design making is a vast iceberg of tacit knowledge. It is a complex web of traditions, work practices, collaboration, skills and knowledge (Göranzon, Hammarén, and Ennals, 2006). Design making involves reflective judgement: our ability to 'read the situation' and 'take the right step at the right time'. It also involves aesthetic expression; our seeing, feeling, imagination and unique ability to transform the thoughts and senses to a language and a form. Design making also contains a moral aspect: our ability to distinguish the feasible from the unfeasible and thus the suitable from the unsuitable. It is the ethical implications in our choices and decisions; it is our responsibility in action (Bergendal, 2003). All these aspects and elements can be separated 'in the moment of making' as little as they can be separated from the maker himself. Therefore, the tacit dimension of knowledge cannot be reliably accessed by traditional analytical approaches. It is necessary to take a detour to the concrete world of making and start to explore and understand it 'in the raw'. Design making is still an essential part of our evolution and our sphere of life in which 'man' is a central figure.

\section{ACKNOWLEDGEMENT}

The author would like to express her thanks to Romanusfonden-Stiftelsen för främjande av uppinnarverksambet that has sponsored this article.

\section{REFERENCES}

Barthes, R. (1964) Bild, förnuft och oförnuft Om encyklopediens planscher. In Weimarck, T. (ed.) Skriftserien Kairos nummer 8

Berg, L. (2005) Gryning över Kalahari, Stockholm: Ordfront Bergendal, G. (2003) Ansvarig handling: Uppsatser om yrkeskunnande, vetenskap och bildning, Dialoger:67-68 Buchanan, R. (2001) Design and the new rhetoric: Productive arts in the philosophy of culture, Philosophy and Rhetoric Vol.34 No.3

Cross, N. (2001) Designerly ways of knowing: Design discipline versus design science. Design Issues 17(3), pp. 49-55

Dewey, J. (2005) Art as experience, New York: Perigee Books (original text from

Göranzon, B., Hammarén, M., \& Ennals, R. (ed.) (2006)

Dialogue, skill and tacit knowledge, West Sussex: John Wiley \& Sons, Ltd

Dorst, K. (2011) The core of 'designthinking' and its application, Design Studies doi:10.1016/j.destud.201107.006

Gadamer, H. G. (2004) Truth and Method, London: Continuum International Publishing Group Ltd, (original text from 1960)

Göranzon, B. (2009) The practical intellect: Computer and skills, Stockholm: Santérus Academic press

Flusser, V. (1999) The shape of things - A philosophy of design, London: Reaction Books

Havemose, K. (2012) Ting i rörelse-Om designprocessen. Stockholm: Santérus Academic press

Johannessen, K. S. (2006) Rule Following, intrasitive understanding and tacit knowledge: An investigation of the Wittgensteinian concept of practice as regards tacit knowing. In Göranzon, B., Hammarén, M., \& Ennals, R. (eds.) Dialogue, skill and tacit knowledge, West Sussex: John Wiley \& Sons, Ltd

Nordenstam, T. (2012) The Power of Example, Stockholm: Santérus Academic press

Sennett, R. (2008) The Craftsman, New Haven: Yale University Press

Tempte, T. (1988) Tuts stol. In Göranzon, B. (ed.) Den inre bilden, Stockholm: Carlssons Bokförlag 